\title{
Development of Candida albicans Hyphae in Different Growth Media - Variations in Growth Rates, Cell Dimensions and Timing of Morphogenetic Events
}

\author{
By MARIA-JESUS SEVILLA† AND F. C. ODDS* \\ Department of Microbiology, University of Leicester, Leicester LE1 7RH, UK
}

(Received 18 February 1986; revised 20 May 1986)

\begin{abstract}
In six liquid culture media, all of which stimulated Candida albicans to grow in the hyphal form, the rates of hyphal extension and increase in cellular ATP concentration, hyphal diameters, times of evagination of hyphae, times of septum formation and positions of septa in the hyphae appeared to vary independently. There were no discernible associations between properties such as length or volume of hyphal compartments at the time of septation and temporal parameters of hyphal growth. The results suggest that growth environment influences many of the processes contributing to hyphal development, but that these processes are not necessarily interrelated.
\end{abstract}

\section{INTRODUCTION}

Considerable information has been published on the cell biological and molecular factors apparently involved in the morphological development of Candida albicans. Stationary-phase yeast-form cells of the fungus can be induced to form hyphal germ tubes in a variety of growth media (Odds, 1985). In developing germ tubes, new cell wall material is synthesized predominantly at the hyphal apex with minimal lateral expansion, whereas in yeast-form cells there is an additional component of generalized wall synthesis that leads to lateral expansion of the cells into an ovoid shape (Staebell \& Soll, 1985). Intermediate forms between parallel-sided hyphae and swollen yeast cells indicate that regulation of lateral wall synthesis is a critical determinant of cell shape (Soll et al., 1985).

Hypha-form cell walls have a higher chitin content than those of yeast-form walls (Chattaway et al., 1968) and plasmalemma-bound chitin synthase activity has been found to be higher in developing $C$. albicans germ tubes than in yeast-form cells (Braun \& Calderone, 1978; Chiew et al., 1980). In hypha-form cells the volume of the cytoplasmic contents appears to remain unchanged from that of the parent yeast cells and the cytoplasm stays in proximity with the developing hyphal apex, so that the hyphae consist of nucleated but vacuolated and collapsible cell compartments behind their growing tips (Gow \& Gooday, 1984; Brawner \& Cutler, 1985).

It is possible that regulation of wall structure and hence cell shape is a phenotypic property rather than the direct result of differential gene transcription (Soll, 1984). Certainly, germ tube development proceeds in the presence of actinomycin D (Oliver et al., 1982) even though this compound blocks induction of enzyme pathways (Bhattacharya et al., 1974a, b), and it proceeds despite a progressively lowered rate of protein synthesis (Torosantucci et al., 1984).

Soll and his coworkers have accounted for developmental events in $C$. albicans in terms of temporal and spatial controls of processes such as emergence of new cell wall material, septum formation and cell wall synthesis (Mitchell \& Soll, 1979a; Bedell et al., 1980; Soll et al., $1981 b$, 1985; Soll, 1984; Staebell \& Soll, 1985).

$\dagger$ Present address: Departamento de Biología, Universidad del País Vasco, Bilbao, Spain.

Abbreviations: AAS, amino acids/salts medium; EMEM, Eagle's minimal essential medium; MAM, methionine assay medium; MSAB, modified Sabouraud broth; NAG, buffered $N$-acetylglucosamine. 
This brief summary appears to present an integrated account of $C$. albicans morphogenesis, but it is entirely eclectic in one important respect: the information comes from experiments with the fungus grown in or on more than five different media. Investigators have rarely studied the consistency of their observations in different hypha-stimulating environments, so it is possible that some of the observations and models in the literature may be based on data related to specific growth environments and are not generally applicable to the development of the fungus. We have therefore undertaken a study of the basic morphogenetic development of $C$. albicans hyphae in six culture media, with emphasis on events during the first $3 \mathrm{~h}$ of growth - the period that has received most previous attention.

\section{METHODS}

Fungus and preparation of inocula. C. albicans isolate 73/055 was used in all experiments. It was maintained on Sabouraud glucose agar (Oxoid Mycological Peptone $10 \mathrm{~g} \mathrm{l}^{-1}$, glucose $40 \mathrm{~g} \mathrm{l}^{-1}$, agar $20 \mathrm{~g} \mathrm{l}^{-1}$ ). For preparation of inocula, yeast cells were grown in Mycological Peptone $10 \mathrm{~g} \mathrm{I}^{-1}$, glucose $40 \mathrm{~g} \mathrm{l}^{-1}$, shaken at 160 r.p.m. at $37^{\circ} \mathrm{C}$ for $24 \mathrm{~h}$. The yeasts were harvested by centrifugation at $2500 \mathrm{~g}$ for $10 \mathrm{~min}$, washed twice with $0 \cdot 1 \mathrm{M}$ citrate buffer $\mathrm{pH} \mathrm{5.0} \mathrm{and} \mathrm{resuspended} \mathrm{in} \mathrm{this} \mathrm{citrate} \mathrm{buffer} \mathrm{overnight} \mathrm{at} 27^{\circ} \mathrm{C}$ to starve the cells. Of several starvation procedures tested, citrate starvation gave the most homogeneous suspensions of single yeast cells for use as inoculum, in our hands.

The starved yeasts were washed twice with water, resuspended in water, and added to culture media to give an initial concentration of $10^{6}$ cells $\mathrm{ml}^{-1}$.

Growth media. The six media and incubation conditions used to examine their effects on hyphal development of C. albicans were as follows: (1) amino acids/salts medium (AAS) (Lee et al., 1975); (2) buffered $N$-acetyl-Dglucosamine (NAG) (Shepherd et al., 1980); (3) horse serum (Difco); (4) methionine assay medium (MAM),

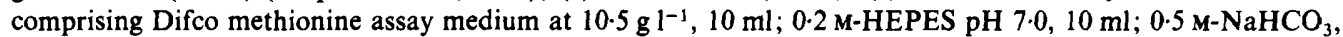
$5 \mathrm{ml}$; water, $75 \mathrm{ml}$; (5) modified Sabouraud broth (MSAB) (Evans et al., 1975); and (6) Eagle's minimal essential medium (EMEM) (prepared according to Odds et al., 1985). The first three media were incubated at $37^{\circ} \mathrm{C}$ in air, shaken at 160 r.p.m. MSAB was shaken in air at $40^{\circ} \mathrm{C}$, and EMEM and MAM were incubated statically at $37^{\circ} \mathrm{C}$ under $5 \%(\mathrm{v} / \mathrm{v}) \mathrm{CO}_{2}$ in air.

Treatment of culture samples. Samples were removed from the culture at zero time, then every $15-30 \mathrm{~min}$ from $1 \mathrm{~h}$ to $3 \mathrm{~h}$, and every 30-60 min up to $7 \mathrm{~h}$. ATP concentrations were measured immediately (Odds, 1982) to determine viable fungal biomass. The remainder of each sample was mixed with 0.1 vol. formaldehyde/sodium dodecyl sulphate preservative solution (Odds et al., 1985) and stored at room temperature for subsequent microscopic examination. Calcofluor was added to samples to a concentration of $200 \mu \mathrm{g} \mathrm{l}^{-1}$ to facilitate microscopic visualization of septa.

Measurement of cell dimensions and other properties. For all samples from $1 \mathrm{~h}$ to $3 \mathrm{~h}$ the following were determined with the aid of a UV/phase contrast microscope equipped with a calibrated eyepiece graticule: the percentage of yeast cells bearing a structure recognizable as a hyphal evagination, the percentage of hyphae with discernible septa, the length and diameter of parent yeast cells, the length and diameter of hyphal outgrowths, and the distance between the septum and the parent yeast/hypha cell junction. For each sample, the percentages were determined by counting of at least 100 yeast/yeast-plus-hypha cell units and the dimensions were calculated from measurements of at least 10 cells. All experiments were repeated twice, and results presented are pooled data from the duplicate experiments.

Calculation of morphogenetic parameters. Growth rates of the fungi were calculated by least-squares regression analysis of plots of $\log$ (ATP concentration) vs time, hyphal extension rates by regression analysis of plots of hyphal length vs time. Hyphal volumes were calculated from the formula $\pi(d / 2)^{2}(l-d / 2)+(2 \pi / 3)(d / 2)^{3}$, where $d$ is hyphal diameter and $l$ is hyphal length. Yeast cell volumes were calculated from the formula for a prolate spheroid: $\left(\pi l w^{2}\right) / 6$, where $l$ is yeast cell length and $w$ is yeast cell width.

\section{RESULTS}

The overall microscopic appearance of $C$. albicans germ tubes/hyphae varied little between the different media, although the lengths of hyphal outgrowths were not always the same at the same culture ages (Fig. 1). In NAG the germ tubes were more slender than germ tubes in the other five media, but in all other respects the hyphae looked similar - phase-dark, parallel-sided structures with a slight constriction at the junction with the parent yeast cell. In later samples, septa were particularly conspicuous in hyphae grown in NAG, but they were visible only with great difficulty in hyphae grown in AAS medium, even with the aid of Calcofluor and UV microscopy. 

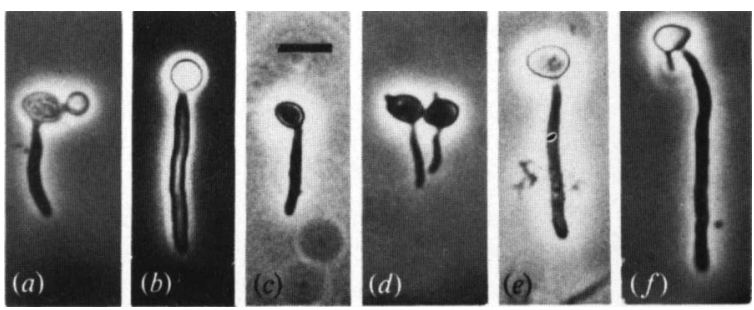

Fig. 1. C. albicans hyphal development after $1.5 \mathrm{~h}$ in (a) AAS medium, (b) EMEM, (c) MSAB, (d) NAG, $(e)$ serum, and after $3 \mathrm{~h}$ in $(f)$ MAM. Bar, $5 \mu \mathrm{m}$.

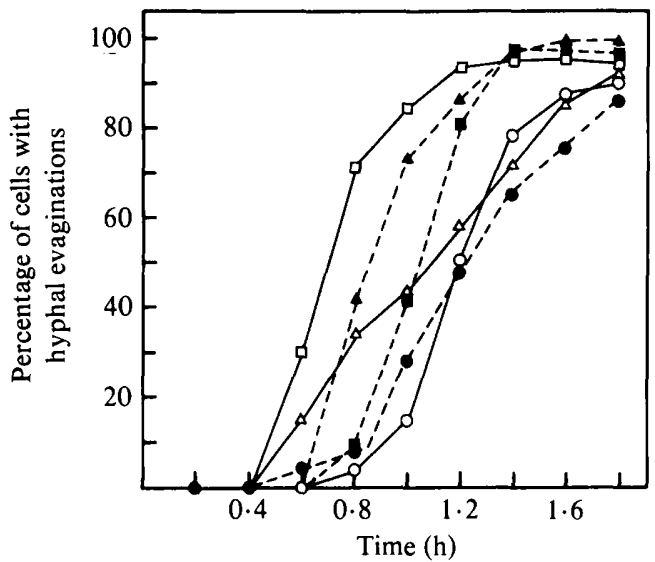

Fig. 2. Evagination of hyphae from parent yeast cells inoculated into AAS medium (O---), EMEM

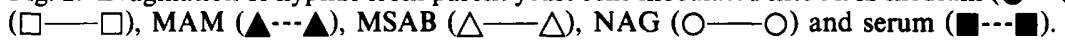

\section{Growth parameters of C. albicans in six liquid media}

C. albicans hyphae developed fairly synchronously in four of the culture media - EMEM, MAM, NAG and serum - but the emergence of hyphal evaginations in AAS and MSAB occurred over a relatively protracted period (Fig. 2).

Fig. 3 shows the exponential changes in fungal ATP concentration with time in the six growth media tested. Linear regression analysis of these plots between $1 \mathrm{~h}$ and $6 \mathrm{~h}$ showed viable biomass growth rates, in terms of ATP increase, ranging from $0.00 \mathrm{~h}^{-1}$ in NAG to $0.80 \mathrm{~h}^{-1}$ in MAM (Table 1). Lag phases in the six media were never more than $1 \mathrm{~h}$ (Fig. 3).

In all six media, $C$. albicans hyphae extended at a linear rate (Fig. 4). The lowest extension rate was $10.9 \mu \mathrm{m} \mathrm{h}^{-1}$ in NAG, and the highest was $21.9 \mu \mathrm{m} \mathrm{h}^{-1}$ in MAM (Table 1). There was thus some correlation between biomass growth rate and hyphal extension rate (Table 1).

The diameters of $C$. albicans hyphae were similar (approximately $2 \mu \mathrm{m}$ ) in five of the six media, but substantially less in NAG (Table 1). Mean diameters of the hyphae grown in MAM and NAG appeared to increase by $0.1-0.2 \mu \mathrm{m}$ between 1.5 and $3 \mathrm{~h}$ of growth; measurements for hyphae in the other four media were consistent throughout this period of growth.

Measurements of the dimensions of the parent yeast cells showed these to have a constant volume of $50-70 \mu \mathrm{m}^{3}$ throughout the first $3 \mathrm{~h}$ of growth (Table 1 ).

\section{Times of evagination and septum formation in different growth media}

Table 1 shows various measurements of developmental events calculated from experimental observations. The times at which $50 \%$ of the yeast cells in the culture bore hyphal outgrowths were calculated by regression analysis of the data for percentage hyphae vs time. They ranged from 40 to $72 \mathrm{~min}$ after inoculation. Regression analysis was also used to calculate the times at 


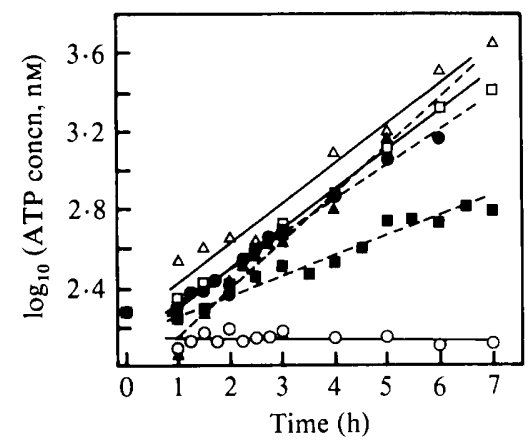

Fig. 3

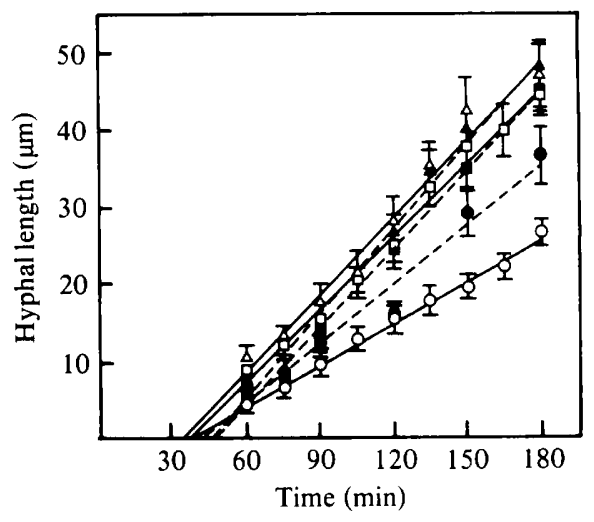

Fig. 4

Fig. 3. ATP concentrations in $C$. albicans hyphae grown in AAS medium (---O), EMEM

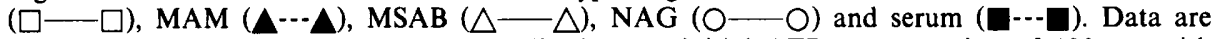
means from duplicate experiments, normalized to an initial ATP concentration of $120 \mathrm{nM}$, with regression lines drawn.

Fig. 4. Hyphal extension of $C$. albicans grown in AAS medium (---O), EMEM ( $\square-\square)$, MAM $(\triangle-\cdots)$, MSAB $(\triangle \longrightarrow \triangle)$, NAG $(\mathrm{O}-\mathrm{O})$ and serum $(\square-\cdots)$. Data are means \pm SEM for at least 20 replicates. Regression lines are drawn.

Table 1. Cell dimensions, growth rates and critical times for C. albicans hyphae grown in six different media

\section{Parameter}

Growth rate $\left(\mathrm{h}^{-1}\right)$ by ATP measurement

Hyphal extension rate $\left(\mu \mathrm{m} \mathrm{h}^{-1}\right)$

Time $50 \%$ cells evaginated $\left(T_{50} ; \mathrm{min}\right)$

Time of hyphal initiation*

Time $50 \%$ hyphae septated $\left(S_{50} ; \mathrm{min}\right)$

Length of hyphae at $T_{50}(\mu \mathrm{m}) \dagger$

Length of hyphae at $S_{50}(\mu \mathrm{m}) \dagger$

Volume of hyphae at $S_{50}\left(\mu \mathrm{m}^{3}\right)$

Volume of parent yeast cells $\left(\mu \mathrm{m}^{3}\right)$

Distance between Mean \pm SD $(\mu \mathrm{m})$

$\begin{aligned} & \text { parent cell and } \\ & \text { septum }\end{aligned}$
Mode $(\mu \mathrm{m})$
AAS

EMEM

$15 \cdot 5$

$\pm 0$

73
34

195

$8 \cdot 1$

$41 \cdot 6$

130

47-67

$1.9 \pm 0$

$3.4 \pm 2.45 .6 \pm \frac{5.7}{3.4} 2.3$

$3 \cdot 3$

0.67

18.9

36

173

$1 \cdot 2$

$43 \cdot 1$

121

MAM

0.80

$21 \cdot 9$

$9 \pm 0$

44

180

$2 \cdot 0$

$49 \cdot 6$

140

$51-66$

$5 \cdot 8$
$3 \pm$

$4 \cdot 5$
MSAB NAG

$0.67 \quad 0.00$

$20 \cdot 1 \quad 10 \cdot 9$

$0+0.31 .2+0.21 .9+0.1$

$\begin{array}{lll}66 & 72 & 63\end{array}$

$\begin{array}{lll}42 & 37 & 47\end{array}$

$\begin{array}{lll}158 & 189 & 142\end{array}$

$\begin{array}{lll}10.8 & 6.4 & 5.6\end{array}$

$\begin{array}{lll}41.6 & 27.6 & 32.5\end{array}$

$130 \quad 31 \quad 91$

48-69 50-60 46-68

* Calculated by extrapolation of data in Fig. 4 to a hyphal length of 0 .

$\dagger$ Determined from data in Fig. 4.

which $50 \%$ of the hyphae contained septa. This time ranged from $142 \mathrm{~min}$ in serum to $195 \mathrm{~min}$ in NAG (Table 1). Extrapolation of the regression curves for the data in Fig. 4 was used to calculate the mean time of initial emergence of hyphae (the time at which mean hyphal length was $0 \mu \mathrm{m}$ ). This time varied from $34 \mathrm{~min}$ in AAS medium to $47 \mathrm{~min}$ in serum.

\section{Distances between yeast cells and hyphal septa}

The distribution of distances between parent yeast cells and hyphal septa was sometimes slightly skewed. Table 1 shows the arithmetic means, modes and median values for this measurement. The data indicate that septa were generally positioned closer to the parent cells in AAS and MAM than in the other media, although the modal septal distance in NAG was also lower than for hyphae in serum, MSAB and EMEM. 


\section{Hyphal lengths and volumes at critical stages of development}

Table 1 lists the lengths and volumes of hyphal outgrowths calculated at the times when $50 \%$ of the cells had visible hyphal outgrowths and when $50 \%$ of the cells contained septa. For four of the media tested, MSAB, AAS, MAM and EMEM, the hyphal lengths and volumes at the time $50 \%$ of the hyphae had formed septa were similar $\left(41-50 \mu \mathrm{m}\right.$ and $120-140 \mu \mathrm{m}^{3}$ respectively), but the lengths and volumes of the hyphae at the $50 \%$ septation time in serum and NAG were less (Table 1).

\section{DISCUSSION}

The literature on morphogenesis in $C$. albicans contains many discrepancies and contradictions concerning dimensions and extension rates of hyphae. Mitchell \& Soll $(1979 b)$ reported that hyphae in AAS had mean dimensions of $11.2 \times 1.5 \mu \mathrm{m}$ at the time of septation, much smaller than the $35.7 \times 2.6 \mu \mathrm{m}$ for hyphae grown on serum agar and measured at the same stage by Gow \& Gooday (1982). The recorded hyphal extension rates in serum- or plasma-based media are $18.7 \mu \mathrm{m} \mathrm{h}^{-1}$ (Gow \& Gooday, 1982), $22.2 \mu \mathrm{m} \mathrm{h}^{-1}$ (Wain et al., 1975) and $39.8 \mu \mathrm{m} \mathrm{h}^{-1}$ (Davies \& Denning, 1972). These figures are all higher than the $4.8 \mu \mathrm{m} \mathrm{h}^{-1}$ found in AAS medium by Soll et al. $(1981 b)$.

The data in the present study agree fairly closely with most published data for $C$. albicans hyphae grown in serum: we found an extension rate of $20.4 \mu \mathrm{m} \mathrm{h}^{-1}$ and a hyphal dimension of $32.5 \times 1.9 \mu \mathrm{m}$ at the time of septation (Table 1). For AAS medium, our figures do not agree at all with those in the literature: we measured the extension rate as $15.5 \mu \mathrm{m} \mathrm{h}^{-1}$, and the dimensions at the time of $50 \%$ septum formation as $41.6 \times 2.0 \mu \mathrm{m}$. It is difficult to believe that differences of this order of magnitude can be explained simply by strain differences between the isolates tested, and even differences of technique should not lead to such discrepancies with relatively simple microscopic measurements.

One possible explanation is that the nutrient status of the $C$. albicans yeast cells used in our experiments differed from that of the yeasts used by Soll et al. (1981b). Soll (1985) has emphasized the significance of zinc starvation of the yeast cells on subsequent developmental events. Whereas in zinc-starved cells there is a delay of approximately $135 \mathrm{~min}$ before $50 \%$ of the cells grow a discernible hyphal evagination, in cells unstarved of zinc this time is reduced to 70-80 min (Soll et al., 1981 a) - a time of precisely the same order as the 73 min recorded in the present study (Table 1). Data concerning septation times and cell dimensions for hyphae grown from a non-zinc-starved inoculum have not been published: however, since our starvation protocol for the yeast cells was not designed to ensure a zinc-depleted inoculum it seems likely that this factor accounts for some, at least, of the differences between our data and those published from Soll's laboratory. The water used in our experiments was distilled, not deionized, and we have experienced extreme difficulty in establishing reproducible conditions for zinc starvation in this laboratory.

Since we observed a large difference in hyphal diameter between cells grown in NAG medium as compared with cells from the other five media tested, we conclude that $C$. albicans is able to alter its hyphal diameter in response to environmental pressures: specifically in response to adverse nutrient conditions, since NAG supported hyphal development but not an increase in viable biomass. It is therefore possible that hyphae grown from inocula which are starved of zinc, like hyphae grown in NAG, attain a diameter less than the approximately $2 \mu \mathrm{m}$ seen in all the nutrient-rich media. This would account for the differences between the hyphal diameter in AAS measured by Mitchell \& Soll $(1979 b)$ and the larger diameters measured by ourselves (Table 1) and by Gow \& Gooday (1982).

We could find no relation between hyphal length or volume and the time at which $50 \%$ of hyphae contained septa, nor was there a constant time between hyphal initiation (whether determined as the time at which hyphal length was 0 or $T_{50}-$ see Table 1) and the time at which $50 \%$ of hyphae contained septa. The distances between septa and parent yeast cells appeared to be independent of the other parameters measured or calculated. In common with Mitchell \& Soll $(1979 b)$ we found an uneven distribution of septum location distances from parent yeast cells. 
Our mean septal distance of $3.8 \mu \mathrm{m}$ (Table 1 ) is greater than the mean of $2.2 \mu \mathrm{m}$ reported by Mitchell \& Soll $(1979 b)$. More importantly, the distances to the septa in cells grown in AAS were markedly smaller than the corresponding distances in hyphae grown in the other five media.

Overall, the rates of cell development, the dimensions of hyphae, the positions of septa and the timings of hyphal emergence and septum formation appear to be independent of each other, but they are all influenced by the growth environment. The mechanisms by which these different processes are coordinated and controlled remain to be elucidated.

\section{REFERENCES}

Bedell, G., Werth, A. \& Soll, D. R. (1980). The regulation of nuclear migration and division during synchronous bud formation in released stationary phase cultures of the yeast Candida albicans. Experimental Cell Research 127, 103-113.

Bhattacharya, A., Banerjee, S. \& DatTa, A. (1974a). Regulation of $N$-acetylglucosamine kinase synthesis in yeast. Biochimica et biophysica acta 374, 384-391.

Bhattacharya, A., Puri, M. \& Datta, A. (1974b). Induction of $\mathrm{N}$-acetylglucosamine kinase in yeast. Biochemical Journal 141, 593-595.

Braun, P. C. \& Calderone, R. A. (1978). Chitin synthesis in Candida albicans: comparison of yeast and hyphal forms. Journal of Bacteriology 133, 14721477.

Brawner, D. L. \& Cutler, J. E. (1985). Changes in surface topography of Candida albicans during morphogenesis. Sabouraudia 23, 389-393.

Chattaway, F. W., Holmes, M. R. \& Barlow, A. J. E. (1968). Cell wall composition of the mycelial and blastospore forms of Candida albicans. Journal of General Microbiology 51, 367-376.

Chiew, Y. Y., Shepherd, M. G. \& Sullivan, P. A. (1980). Regulation of chitin synthesis during germtube formation in Candida albicans. Archives of Microbiology 125, 97-104.

Davies, R. R. \& DenNing, T. J. V. (1972). Growth and form in Candida albicans. Sabouraudia 10, 180-188.

Evans, E. G. V., OdDs, F. C., Richardson, M. D. \& Holland, K. T. (1975). Optimum conditions for initiation of filamentation in Candida albicans. Canadian Journal of Microbiology 21, 338-342.

Gow, N. A. R. \& GoODAY, G. W. (1982). Growth kinetics and morphology of the filamentous form of Candida albicans. Journal of General Microbiology 128, 2187-2194.

Gow, N. A. R. \& Gooday, G. W. (1984). A model for the germ tube formation and mycelial growth form of Candida albicans. Sabouraudia 22, 137-143.

LEE, K. L., BuCKLEY, H. R. \& CAMPBell, C. C. (1975). An amino acid liquid synthetic medium for the development of mycelial and yeast forms of Candida albicans. Sabouraudia 13, 148-153.

MitChell, L. H. \& Soll, D. R. (1979a). Commitment to germ tube or bud formation during release from stationary phase in Candida albicans. Experimental Cell Research 120, 167-179.

MitChELl, L. H. \& Soll, D. R. (1979b). Temporal and spatial differences in septation during synchronous mycelium and bud formation by Candida albicans. Experimental Mycology 3, 298-309.

ODDs, F. C. (1982). Interactions among amphotericin B, 5-fluorocytosine, ketoconazole, and miconazole against pathogenic fungi in vitro. Antimicrobial Agents and Chemotherapy 22, 763-770.

ODDs, F. C. (1985). Morphogenesis in Canaida albicans. CRC Critical Reviews in Microbiology 12, 45-93.

Odds, F. C., Cockayne, A., Hayward, J. \& Abbott, A. B. (1985). Effects of imidazole- and triazolederivative antifungal compounds on the growth and morphological development of Candida albicans hyphae. Journal of General Microbiology 131, 25812589.

Oliver, G., De Ruiz Holgado, A. P. \& Salim, R. (1982). Dimorphism in Candida albicans, effect of cycloheximide and acridine orange on germ tube formation. Mycopathologia 79, 43-47.

ShePherd, M. G., ChIEW, Y. Y., RAM, S. P. \& Sullivan, P. A. (1980). Germ tube induction in Candida albicans. Canadian Journal of Microbiology 26, 21-26.

SolL, D. R. (1984). The cell cycle and commitment to alternate cell fates in Candida albicans. In The Microbial Cell Cycle, pp. 143-162. Edited by P. Nurse and E. Streiblová. Boca Raton, Florida: CRC Press.

Soll, D. R. (1985). The role of zinc in Candida dimorphism. In Current Topics in Medical Mycology, pp. 258-285. Edited by M. R. McGinnis. New York: Springer-Verlag.

Soll, D. R., Bedell, G. W. \& Brummell, M. (1981 a). Zinc and the regulation of growth and phenotype in the infectious yeast Candida albicans. Infection and Immunity 32, 1139-1147.

Soll, D. R., Bedell, G., Thiel, J. \& Brummel, M. $(1981 b)$. The dependency of nuclear division on volume in the dimorphic yeast Candida albicans. Experimental Cell Research 133, 55-62.

Soll, D. R., Herman, M. A. \& Staebell, M. A. (1985). The involvement of cell wall expansion in the two modes of mycelium formation in Candida albicans. Journal of General Microbiology 131, 23672375.

Staebell, M. \&. Soll, D. R. (1985). Temporal and spatial differences in cell wall expansion during bud and mycelium formation in Candida albicans. Journal of General Microbiology 131, 1467-1480.

Torosantucci, A., Angiolella, L., Filesi, C.. \& Cassone, A. (1984). Protein synthesis and amino acid pool during yeast-mycelial transition induced by $N$-acetyl-D-glucosamine in Candida albicans. Journal of General Microbiology 130, 3285-3293.

Wain, W. H., Price, M. F. \& Cawson, R. A. (1975). A reevaluation of the effect of cysteine on Candida albicans. Sabouraudia 13, 74-82. 